\title{
CASE OF LATVIA IN THE EVALUATION OF ADULT EDUCATORS: ISSUES AND SOLUTIONS
}

\author{
Tamara Pigozne
}

University of Latvia

\section{Svetlana Usca}

Rezekne Higher Education Institution

\begin{abstract}
In the context of research the evaluation of adult education is analyzed as a process and outcome, emphasizing the evaluation of performance; goals are related to the assurance of quality and sustainability according to learners' needs; competence indicators are methodology, motivation, communication and management; evaluation involves selfevaluation, external evaluation and consolidation.

The goal of the article is to analyze the experience of adult educators in the field of evaluation. Methods - analysis of literature and interviews with Latvia's education policy makers and implementers in AQUAD environment.

The authors of the article offer the model for evaluation of competence of adult educators' assessors and analyze the real situation of adult educators' evaluation in Latvia.
\end{abstract}

Keywords: adult education, quality of education, evaluation of adult education, competence, self-evaluation, performance evaluation.

\section{Introduction}

In European education space in the context of adult education the issue of the evaluation of the quality of education services has become increasingly topical, as well as evaluators of adult educators are regarded as an important evaluation resource. Although within the framework of different projects (VALNET, 2013) implemented in Latvia the best solutions for the evaluation of adult education have been searched for and the tools for evaluation of adult educators' competences have been developed (CAPIVAL, 2012), there is still no united evaluation system.

The project „Evaluation for the Professional Development of Adult Education Staff" (EDUEVAL), involving researchers and volunteers from Italy, Spain, Greece, Poland, and Latvia, focuses on adult educators' evaluation, which is viewed as an important educational system, as well as the part of the training process, which ensures a sustainable quality of education.

\section{Theoretical background}

The topical issue in the context of the study is the understanding of the quality of education as the transformation. Basing on this approach, the quality of adult education is defined as a set of characteristics and properties, which characterizes education as a process and education as an outcome of continuous 
improvement that comply with the changing requirements and needs of individuals and all other interested parties (Fernāte, 2014: 12). The need is an essential tool for achieving success; it is the basis for motivation (Deci \& Ryan, 2008; Zepeda, 2011).

There can be observed differences in the understanding and evaluation of the quality of adult education of Latvia among the persons involved in the educational process and employers (educators and learners): educators and learners relate educational awareness, as well as the evaluation, to individual interests, needs and abilities, while employers emphasize compliance with the needs of labour market and socio-economic development of the country (Fernāte, 2014).

In today's context in the adult education and educators' evaluation system there should be viewed both visions. In pedagogical aspect the evaluation is a person's targeted activity, which reveals personal, intellectual and social development (Ксендзова, 2001). Basing on the acknowledgment that one of the key indicators of education quality, alongside the quality of learners (learning motivation, certain abilities and skills) and education as a process of quality, is the quality of the educator (Panina, 2007), there raises the issue on how and what should be evaluated in order to have an objective adult educators' evaluation and to contribute to the improvement of quality in the long run. Searching for answers, there have been implemented several significant projects in Europe over the last decade.

Within the framework of the project ,,AGADE - A Good Adult Educator in Europe" (2006) there was developed a minimum of criteria and competencies for adult educators. There was put an emphasis on personal development/ethical dimension and professional development dimension, which were divided into three stages: organization (knowledge), performance (skills), evaluation (organization) (Carlsen \& Irons, 2003; Jääger \& Irons, 2006). In the following years within the framework of the project "Qualified to Teach" (2009) there was developed international qualification system for promoters of adult education in adult initial training and continuing education in Europe, structuring qualification descriptions in 3 domain areas, where pedagogical triangle as an analytical category reflects 3 key pedagogical elements that must be combined in pedagogical activities:

- $\quad$ content and didactics (basic competencies connected with the goal);

- $\quad$ personal development and professional identity (basic competencies related to the promotion of learning);

- learners' support (basic competencies related to the learner).

There have been developed (Research voor Belied, 2010) indicators for self evaluation of adult educator's basic competencies (see. Figure 1). 


\section{Profile of evaluation of basic competencies}

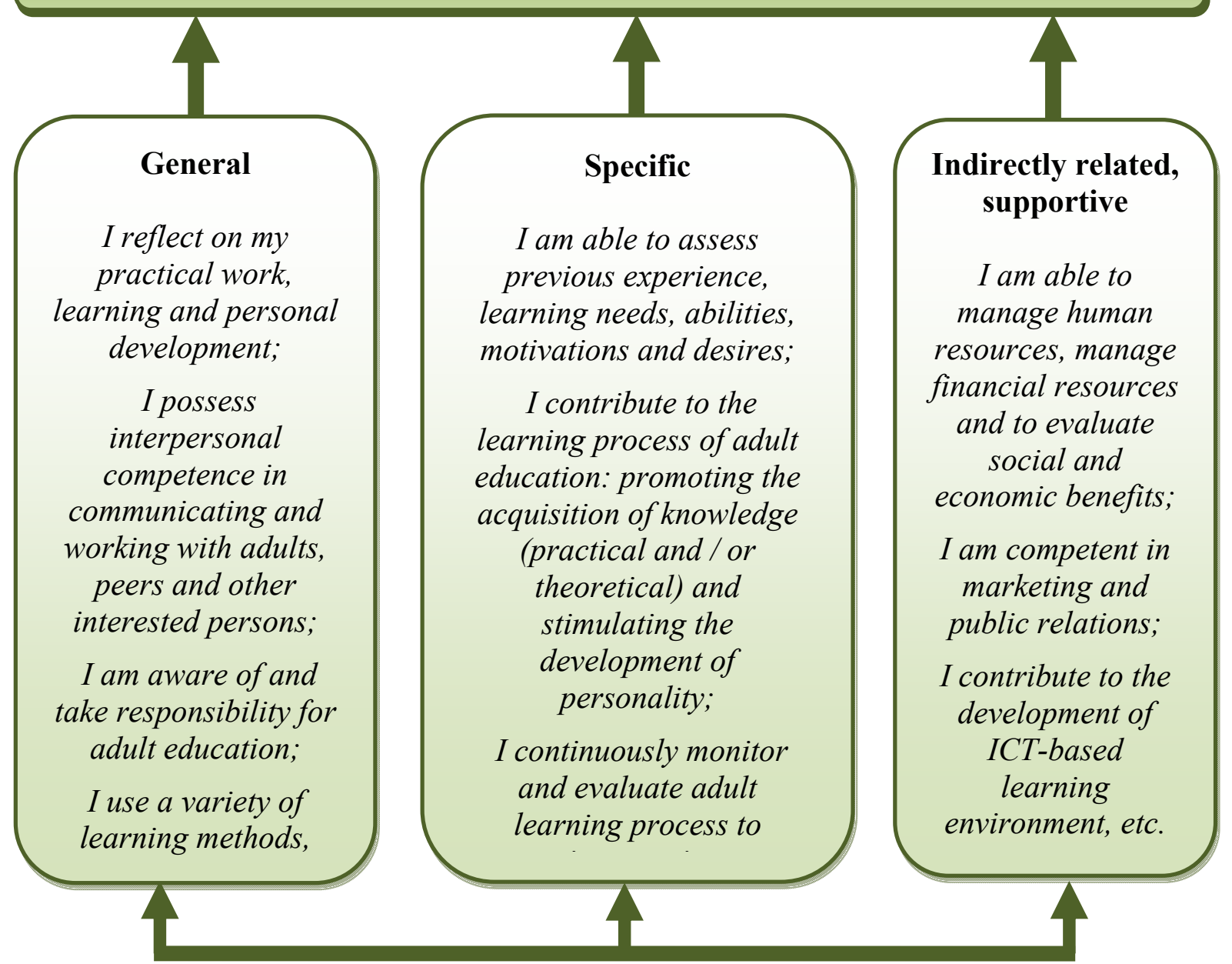

Figure 1. Profile of evaluation of basic competences

(according to Research voor Belied, 2010)

The components of adult educators' competence model elaborated by L. Garrido, G. Levi, A. Medina and E. Mendeza (Garrido, Levi, Medina \& Méndez, 2014) are institutional affiliation, innovation, research, evaluation, motivation, planning, professional identity, media integration, methodology, communication, tutoring and intercultural communication. It is emphasized that adult educators' competence is an important factor in evaluating the quality of adult education (EAEA, 2006).

In order to assess the competence-based learning environment, testing methods are based on the model created by M. Jaspers and I. HeijmenVersteegen (Jaspers \& Heijmen-Versteegen, 2004) that is based on the testing functions (monitoring and evaluation, the role of feedback) and focuses on testing (process and results). In order to provide supervisory functions when developing digital portfolio it is recommended to use coaching, personal development and action plan, reflexive report, the test on progress, learning style, personality and practice, while for the provision of evaluation functions 
there is used the feedback, evaluating discussion, using criteria based interview method, an essay, a knowledge test, case studies, simulations, qualification test, presentations, the final project / thesis. Self-evaluation, peer evaluation and joint evaluation are the basis for monitoring testing methods that are oriented to both the process and the result.

There are three main phases in the adult educators' evaluation process:

- self-evaluation (consists of „reflectivity” biography, learning process/ learning outcome competences);

- external evaluation (monitoring and evaluation with the help of the checklist of the observation of basic competences);

- consolidation (portfolio of consolidated outcomes) (Lupou, 2010; Vinepac, 2008a, 2008b).

Evaluation criteria is an essential condition for qualitative self-evaluation (Santos \& Pinto, 2014), which, in authors' opinion, is one of the main forms of adult education evaluation. Quantitative or criterial evaluation is determination of quality using criteria; its alternative is the determination of quality through subjective experience, using a description, analysing success/merits and shortcomings/failures (Stake, 2004).

A process and a result are important components of adult educators' evaluation (Jaspers \& Schade, 2002). Under the influence of modern pedagogical paradigms the focus is put on the process-oriented evaluation. It helps to see the relationship between causes and consequences, evidence that supports the results or impact of the supportive intervention (Nagao, 2003; Jaspers, 2003; Jääger \& Irons, 2006), provides a more active participation of the interested parties in the evaluation, decision-making and implementation process (Smith, 2005), as well as ensures sustainability (Hashimoto, Pillay \& Hudson, 2011).

Process oriented evaluation is related to the assessment of the performance, which is defined as the assessment of integrated action and behaviour in the definite situation, which is relevant to the profession (Van Brakel \& HeijmenVersteegen, 2003). In order to assess the competencies that are specific to the profession or have a key role there is used a testing method. Standardized observation is also used in evaluation process. It is done by qualified assessors who are specially trained to observe, record and evaluate. This will guarantee possibly the highest reliability. It is a problem in Latvia because of regulatory documents, which do not clearly define competences of adult educators' evaluators. Assessors are specially trained for successful implementation of the evaluation process, but the relevance and quality of the process is still a controversial issue. 


\section{Research methodology}

In order to find out how the persons involved in the process understand adult educators' evaluation, the project volunteers in Latvia, using structured interviews, carried out interviews with 5 adult education policy-makers and 11 adult education policy implementers. Basing on the theoretical statement there was developed a code system, which consists of respondents' codes and content (conceptual) codes (see Table 1.). Structured interviews were coded according to the code system and the obtained data was processed in the program AQUAD 6, forming frequency tables for determining the frequency of codes and regularities of conditions. To determine the relationship between the groups of respondents there was used Chi-Square test, but to determine correlation there was applied Kendall's tau-b correlation analysis.

Table 1. Code structure

\begin{tabular}{|c|c|c|}
\hline \multirow[t]{2}{*}{ Profile codes } & \multicolumn{2}{|c|}{ Content (conceptual) codes } \\
\hline & Meta-codes & Multiple codes \\
\hline \multirow{13}{*}{$\begin{array}{l}\text { - adult education policy makers } \\
\text { - adult education policy } \\
\text { implementers }\end{array}$} & \multirow[t]{3}{*}{ - understanding } & - process \\
\hline & & - result \\
\hline & & - process result \\
\hline & \multirow[t]{3}{*}{ - goal } & - quality \\
\hline & & - sustainability \\
\hline & & - needs \\
\hline & \multirow[t]{3}{*}{ - evaluation } & - self-evaluation \\
\hline & & - external \\
\hline & & - consolidation \\
\hline & \multirow[t]{4}{*}{ - competence } & - methodology \\
\hline & & - communication \\
\hline & & - management \\
\hline & & motivation \\
\hline
\end{tabular}

\section{Research Results and Discussion}

Most of the adult education policy-makers (4) and education policy implementers (10) believe that external evaluation is a dominant component in adult educators' evaluation process, which is carried out by the administration, colleagues and learners within the institution, but at the national level it is done by educational program licensing and accreditation commission in accordance with the criteria developed and approved by education policy implementers. Only one adult education policy maker and one adult education policy implementer mentioned consolidation of self-evaluation and external evaluation. Adult education policy-makers pointed out the compliance of adult educators' evaluation quality control and situation monitoring with both national and international standards, as well as its continuity, emphasizing that it is an 
integral part of everyday life in Latvia. In structured interviews adult educators suggested that learners, who understand and are aware of their needs, are the best evaluators, indicating that the assessment is the measurement of the added value obtained by students.

By analyzing the positive experience of evaluation, respondents emphasized the need for objectivity provided by the diversity of methods, the use of criteria, balance of the types of assessment, orientation to the process, performance assessment and positive experience, dynamics of growth, cooperation between all parties involved in the evaluation process providing professional growth and emotional well-being:

Multivariate assessment, where is the balance between self-evaluation and the evaluation of administration and colleagues; where have been developed specific criteria, such as portfolio, where the applicant has the opportunity to practically demonstrate his achievements, examples of good practice and positive experience.

Dynamics is taken into account - personal growth and each person's contribution in the growth in collaboration with the teacher, as well as his attitude; not only the result but also the process is evaluated - how productive it was.

Most often, it is the learner's satisfaction with the benefits gained from the educational process and practical application in the situations of life and work.

Evaluating people by performed activities and viewing their professional and personal qualities of cooperation.

It is also important to evaluate the teacher's growth. Not only to document the current situation, but to compare it with the previous one.

When the participants and the teacher feel pleased with the accomplished work and know what else could be done better and apply the acquired knowledge in their work.

Respondents expressed the idea that in adult educators' evaluation the focus should be put on self-evaluation, where the person, who is assessed, is the most professional and best evaluator, because only he and not anyone else can evaluate appropriately all aspects, contexts and situations.

By contrast, respondents consider that a negative evaluation of adult educators is:

- formal, subjective, biased, uniform (only documentation is evaluated, knowledge rather than its practical application is tested; it does not give a positive solution to the identified problem);

- there are no specific criteria, it is done by the administration and functionaries (by the people, who are not familiar with the context and situation)

- when adult educators are evaluated through the process and the result, they feel emotional discomfort (there are errors in 
communication or there are violated ethical principles; blaming or admonishment appears in evaluation);

- $\quad$ growth and dynamics are not taken into account (when the obtained evaluation is not compared with the situation that the recipient had before - whether he has developed his skills, or has remained unchangeable).

Most of the adult education policy-makers (3) and education policy implementers (8) consider adult educators' evaluation as the result concerning the evaluation of knowledge, skills and competences and in determining adult educators' quality and they believe that ( 2 adult education policy-makers and 6 adult education policy implementers) the goal of adult educators' assessment is sustainability. Adult education policy-makers mentioned quality as one of the main goals of adult educators' evaluation (2).

The analysis of interviews points to the need to prepare evaluators of adult educators for evaluation process so that it would not be formal, but the evaluator would be able to go into the real situation, to assess not only the quality of the definite moment, but to view its dynamics, carrying out a comparative analysis of previous results and prospects for development. Respondents' answers demonstrate the same conclusion with the emphasis on sustainability as the goal of adult educators' evaluation: further cooperation, students wish to return, image of the institution, long term application of acquired knowledge and skills, improvement of the process, gathering information, like it is currently being implemented and on its base carrying out improvement, development or creation of something new.

Respondents, who associate the goal of adult educators' evaluation with learners' needs, are of the opinion that the most important is the service recipients' point of view, satisfying participants' demand (whether and to what extent they are satisfied with the benefits of a learning process and to what extent it is necessary for their professional development), which, in their opinion, makes the service providers change so that they would be required; offer should be topical, qualitative and available to the recipient.

Chi-Square test results show that there is a statistically significant relationship between the evaluation of respondents' status and aspects of adult educators' competence $\left(\chi^{2}=9.270 ; \mathrm{p}<0.05\right)$ : the respondents' status influence the understanding of competence.

Education policy-makers consider that when evaluating adult educators' competence the focus is put on management (3) and communications (2). However, the majority of adult education policy makers (5) believe that in the assessment of adult educators' competence the emphasis is put on methodology. 3 adult educators responded that the criterion for adult educators' competence is management, 2 - motivation, but 1 person mentioned communication as a criterion for adult educators' competence. 
Management evaluation highlights:

- $\quad$ professional aspect (it is important to have the ability to perform the tasks necessary for professional work; or those who teach others, have increasingly high results);

- $\quad$ aspect of human resources (the ability to work with the audience, activities and participants' responsiveness and participation in workshops, finding balance, when all students feel equally involved in the process);

- $\quad$ environmental aspects (availability of education to society).

In assessment methodologies there have been identified indicators such as:

- integrative approach (lesson structure, content, teaching methods, unified content, themes complement each other), emphasizing the principle of the unity of form and content;

- compliance (ability to use appropriate methods for adult education, a balanced proportion of theory and practice);

- innovations (essential topicality of the course program theme, technical equipment appropriate to the requirements of contemporary requirements and the ability to use it; applied creative solutions).

In the communication there is emphasized the ability to interact and „unleash" the audience, teamwork, organizing exciting teaching and learning process, flexibility, adapting to different situations, as well as attitude towards colleagues.

Respondents' most often mentioned answer was an external motivation, where the most important is recipient's point of view and the ability to use acquired skills and competences. In the result of the analysis of research data when processing qualitative data in the program AQUAD environment there were identified the evaluation implicants- evaluation is affected by its purpose and understanding ( 2 cases).

There were found the implicants of consolidation of self-evaluation and external evaluation that is influenced by the evaluation goals, such as quality and needs, understanding of the evaluation as the process and as the result, as well as indicators of adult educators' competences such as management and communication (3 cases).

The evaluation process has also been considered as the understanding of the implicants of the process and the result - they are influenced by the consolidation of self-evaluation and external evaluation, the goals of evaluation like quality and needs, as well as indicators of adult educators' competence like management and communication ( 3 cases).

The results of Kendall's tau-b correlation analysis show that there is a medium positive correlation between the needs as the evaluation goal and motivation as the indicator of adult educators' competence $(\mathrm{p}=0.022$; $\mathrm{r}=0.59$ ) - adult educators' needs affect motivation. 
Still a topical issue is connected with appropriate evaluation methods. Respondents' point of view is that the most commonly used methods for assessing the competence of adult educators are observations and interviews (see Figure 3). Observations were mentioned by all education policy-makers $(100 \%)$ and $82 \%$ of education policy implementers, but discussions were mentioned by $80 \%$ of adult education policy-makers and $73 \%$ of adult education policy implementers. Adult education policy implementers are of the opinion that tests $(64 \%)$ and other methods $(55 \%)$ are frequently used in adult educators' assessment.

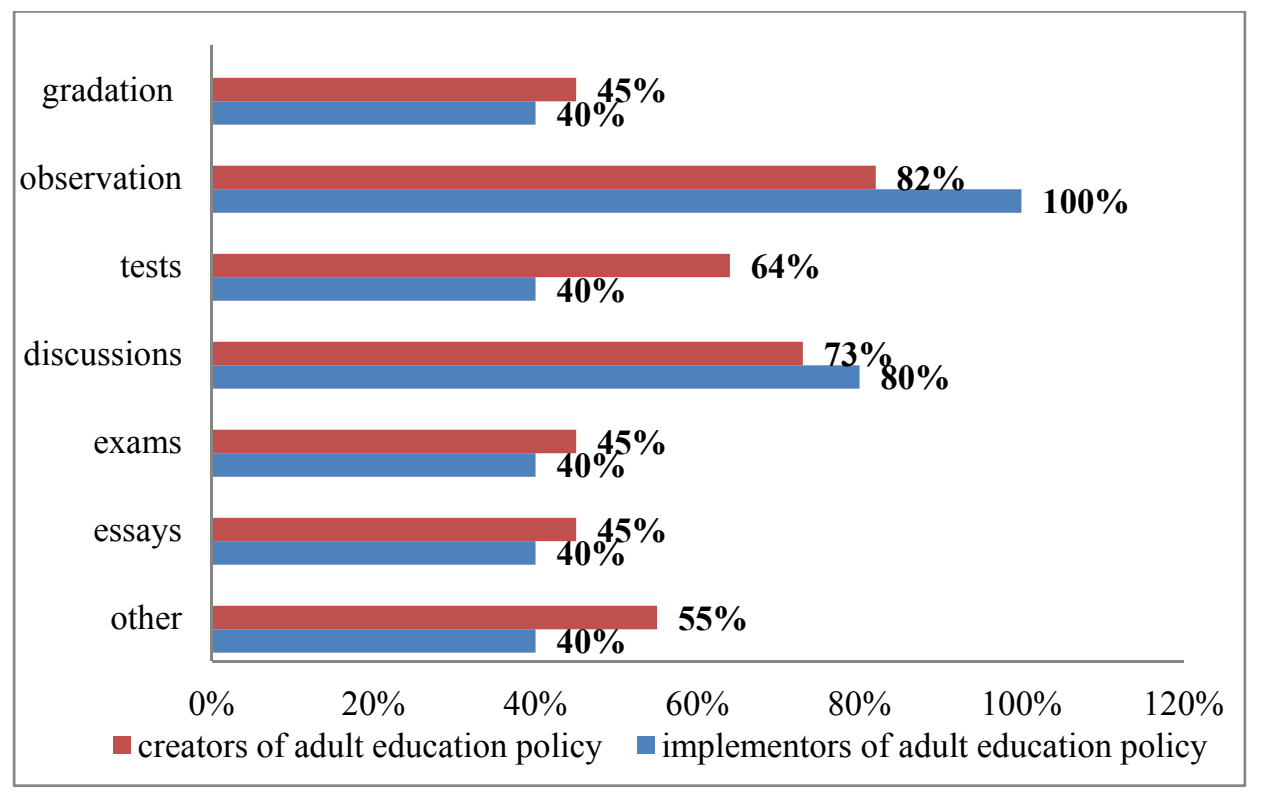

Figure 2. Application of evaluation methods in the assessment of adult educators' competence

The results of Kendall's tau-b correlation analysis show that there is a high positive correlation between the evaluation methods of adult educators' competence such as exams and tests $(\mathrm{p}=0.003 ; \mathrm{r}=0.78)$, as well as exams and essays $(\mathrm{p}=0.004 ; \mathrm{r}=0.74)$ - adult educators more frequently use tests and essays in exams.

The results of Kendall's tau-b correlation analysis show that there is a medium positive correlation between external evaluation and discussion $(\mathrm{p}=$ $0.011 ; \mathrm{r}=0.65)$ as well as external evaluation and methodology as the indicator of competence - external evaluation in negotiations more often is evaluated as the methodology.

The results of adult educators' assessment are used, firstly, in the context of personality - improvement and increase of working quality, as well as for adult educators' motivation and growth; secondly, in micro (educational institutions) context - the identification of the actual situation, growth of the institution, based on the learners' needs, development of the strategy.

Problems identified in the adult educators' evaluation: 
- lack of information (although there is a very broad offer for assessment procedures, it is hard to find what is necessary, effective and gives benefits);

- lack of evaluation system and criteria (a lack of a clear assessment concept; it would be good if there were some kind of holistic approach or a single model to eliminate or reduce subjectivity and to have adequate assessment and to have clear criteria or parameters) and the lack of methodology (it must be learned how to assess);

- contradictions between educational standards and recipients' wishes, needs and requirements (provision of feedback, searches for correlation between learners' preferences and professional aptitude, where standards of education are high, but the recipients of the service have sometimes a desire to lower standards);

- communication problems (it is necessary to improve personal attitude to seek solutions to new situations, which will never come to an end. These are the signs of the processes of life and tolerance during the evaluation);

- formal approach (questionnaires are given to a small group, and they are not anonymous and out of respect of some teachers they are filled out formally).

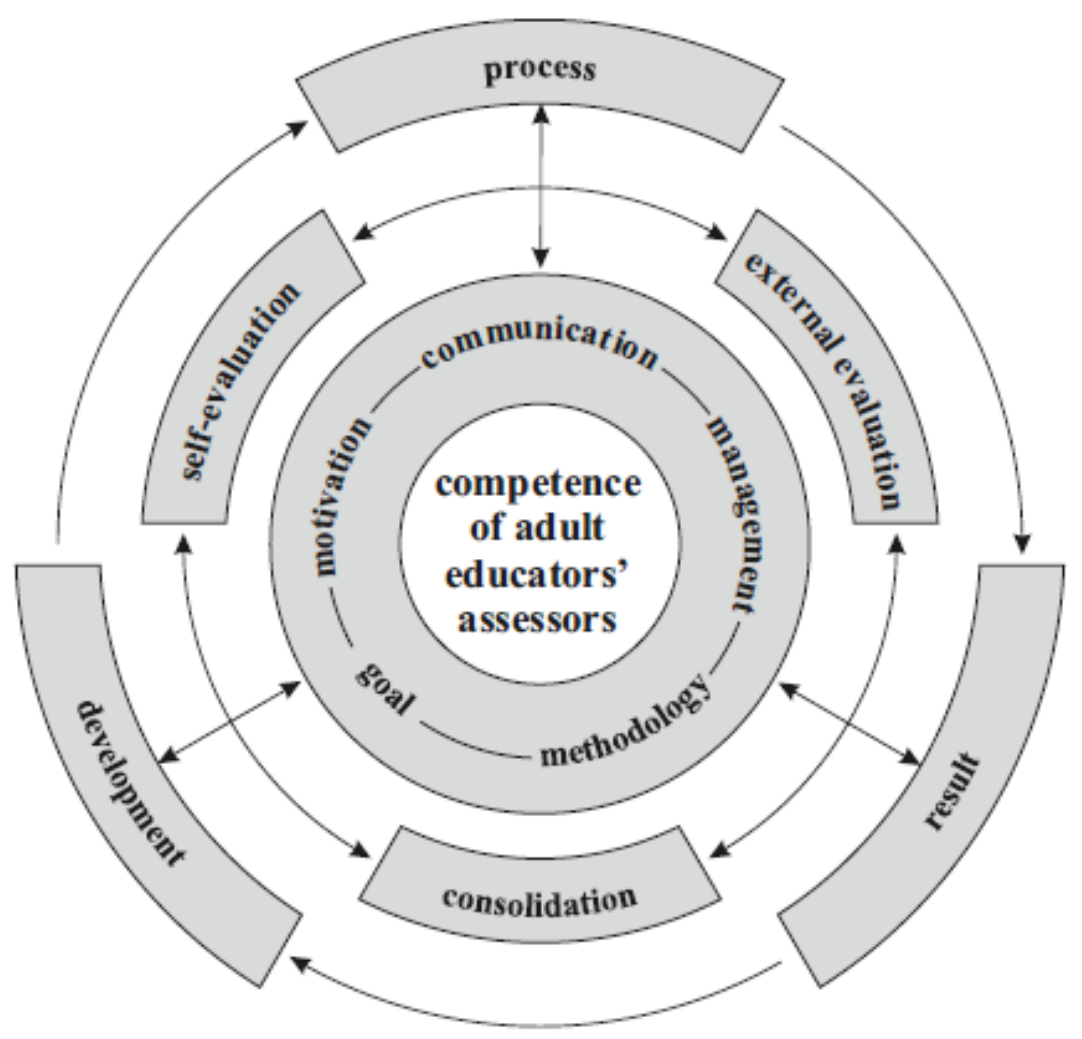

Figure 3. Model for evaluation of competence of adult educators' assessors 
Basing on the theoretical statements and results of empirical research, the authors offer the model for evaluation of competence of adult educators' assessors, which could be the basis for the evaluation of competence of adult educators' assessors (see Figure 2), and which analyzes the assessment as a process and a result, emphasizing the assessment of performance; goals are related to the provision of quality and sustainability according to learners' needs; competence indicators is methodology, motivation, communication and management; evaluation includes consolidation of self-evaluation and external evaluation. Basing on the analysed literature and the proposed model, the authors define the competence of assessors of adult educators as a metacompetence, where general and professional competences closely synergize with the evaluator's personal qualities and objectivity and focus on the evaluation of educator's actions and behaviour in the definite educational context, as well as facilitate sustainable improvement of the existing process (activities).

The authors are of the opinion that it is necessary to carry out further studies to understand in-depth the situation of adult education in Latvia. The research would be the basis for the development of the regulatory base and there would be specified competence of assessors of adult educators and organized their training.

\section{Conclusions}

1. Evaluation of competence of adult educators' assessors is the process and the result, where it is important to assess performance, goals related to the assurance of quality and sustainability according to learners' needs, as well as competence indicators: methodology, management, communication and motivation. Evaluation involves consolidation of self-evaluation and external evaluation.

2. Competence of adult educators' assessors is meta-competence, where general and professional competences closely synergize with the evaluator's personal qualities and objectivity and focus on the evaluation of educator's actions and behaviour in the definite educational context, as well as facilitate sustainable improvement of the existing process (activities).

3. In Latvia it is necessary to improve the regulatory documents, defining the competences of adult educators and their assessors. On this basis, it is necessary to develop an evaluation system and to elaborate evaluation criteria corresponding to the education sector.

4. The compliance of evaluation criteria with the field of education and training of assessors of adult educators could provide objective and qualitative evaluation, contributing to the increase in quality of adult education. 


\section{Acknowledgements}
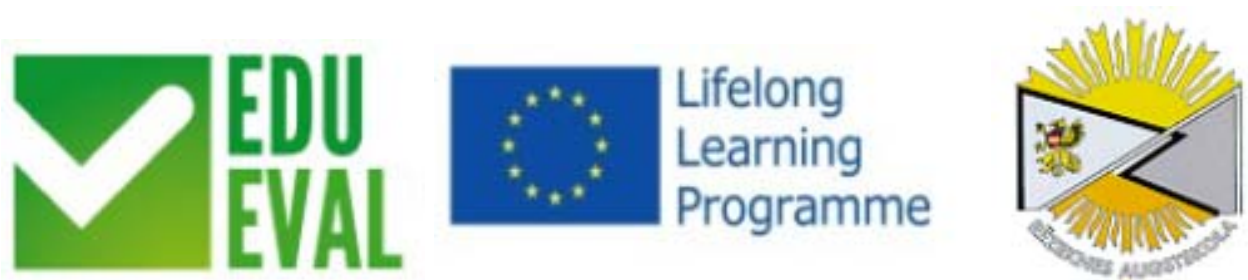

This publication reflects the views only of the authors, and the Commission cannot be held responsible for any use which may be made of the information contained there in.

\section{References}

Care Competencies of Adult Learning Facilitators in Europe Findings from a Transnational Delphi Servey. Conducted by the Project „Qualified to Teach”. Nils Bernhardsson / Susanne Lattke (eds.) (2009). Available at http://asemllhub.org/fileadmin/ www.dpu.dk/ASEM/events/RN3/QF2TEACH_Transnational_Report_final_1.pdf [Retrieved on January, 2015]

Carlsen, A., Irons, J. (eds.) (2003). Learning 4 Sharing: Manual for Adult Education Practitioners, Vilnius, pp.23-28.

Deci, E.L., Ryan, R.M. (2008). Self-Determination Theory: A Macrotheory of Human Motivation, Development, and Health. Canadian Psychology, Voume. 49, No. 3, pp.182-185.

European Association for Education of Adults (EAEA) (Ed.) (2006). Adult education trends and issues in Europe. Brussels: EAEA.

Fernāte, A. (2014). Pieaugušo izglītības kvalitāte un tās nodrošinājums. Ziņojums. Available at

http://izm.izm.gov.lv/upload_file/Izglitiba/Muzizglitiba/projekts/Zin_PI_kvalitate_A_F ernate_2014_1.pdf

Garrido, C.D., Leví, Orta G.C., Medina, Rivilla A., Méndez, E. R. (2014). Las competencias docentes: diagnóstico y actividades innovadoras para su desarrollo en un modelo de educación a distancia. In: Revista de docencia Universitaria. Vol 12 N1, Enero - Abril, 2014, pp.239-268.

Hashimoto, K., Pillay, H., Hudson, P., (2011). An evaluation framework for sustaining the impact of educational development. In: Studies in Educational Evaluation (36), pp.101110.

Jääger, T., Irons, J. (ed.) (2006). Towards becoming a good adult educator. Resource book for adult educators. URL: http://www.vabaharidus.ee/public/files/LPIA_Agade_A4.pdf

Jaspers, M. \& Schade, M.(2002). Toets \& Beleid, organisatiegestuurd toetsbeleid en geautomatiseerde toetsing. Eindhoven: Fontys Hogescholen.

Jaspers, M., Els van Zijl (2011). Kwaliteit van toetsing in het Hoger Onderwijs. Mission Statement East Valley Institute of Technology, Mesa, Az, Dienst Onderwijs en Onderzoek.

Jaspers, M. (2003). Toetsing, een strategische keuze. Kadernotitie Fontys visie en beleid ten aanzien van toetsing. Eindhoven: Fontys Hogescholen.

Jaspers, M., Heijmen-Versteegen, I. (2005). Toetswijzer competentiegericht begeleiden \& beoordelen in het Hoger Onderwijs. Eindhoven: Fontys Hogescholen.

Jaspers, M., Heijmen-Versteegen, I. (2004). Toetswijzer competentiegericht begeleiden en beoordelen in het hoger onderwijs. http://www.fontyspublicaties.nl/show.cgi?fid=81.

Key competences for adult learning professionals. Contribution to the development of a reference framework of key competences for adult learning Professionals. Final report 
(2010). Available at http://www.ginconet.eu/sites/default/files/library/keycompetences AE_professionals.pff [Retrieved on January, 2015]

Linke, D. (2000). Eisteins Doppelganger. Das Gehirn und sein Ich. Munchen: C.H.Beck Verlag, S.150.

Lupou, R. (2010). Validation of Adult Educators' Competences: European Need, Solution and Transfer of Innovation to New Contexts. Teachers and Trainers in Adult and Lifelong Learning. European and Asian Perspectives. Egetenmeyer, R. and Nuissl, E. (eds.) Peter Long Verlag, Frankfurt am Main, pp.167-176.

Nagao, M. (2003). Kyoiku Enjyo Hyoka no Genjyo to Kadai (Present concerns and issues in evaluation of educational cooperation). Journal of International Cooperation in Education, 6(1), pp.1-18.

Nagao, M. (2006). Challenging times for evaluation of international development

assistance. Evaluation Journal of Australia, 6(2), pp.28-36.

Paņina, L. (2007). Izglītības kvalitātes elementi izglītības sistēmā iesaistīto grupu vērtējumā. R.: Zinātne, 52.-73.lpp.

Parylo, O. (2012). Evaluation of educational: A decade review of research (2001-2010). In: Studies in Educational Evaluation (38), pp.73-83.

Santosa, L., Pinto, J. (2014). The development of self-regulation through assessment criteria. Procedia - Social and Behavioral Sciences, vol. 112, pp.907 - 915.

Smith, H. (2005). Ownership and capacity: Do current donor approaches help or hinder the achievement of international and national targets for education? International Journal of Educational Development, 25, pp.445-455.

Stake, R. (2004). Standards-based and responsive evaluation. Thousand Oaks, CA: Sage

Van Brakel, G., Heijmen-Versteegen, I. (2003). Continu zicht. [Continuous view]. Eindhoven: SKIF.

Vinepac (2008a). Handbook for the Use of Validpack for the Validation of Psychopedagogical Adult Educator's Competences. Sava, S.; Lupou, R. (coord.). Timisoara. Available at http://www.capival.eu/images/handbook.pdf [Retrieved on December, 2014]

Vinepac (2008b). Evaluator's Guide for the Use of Validpack for the Validation of Psychopedagogical Adult Educator's Competences. Sava, S.; Lupou, R. (coord.). Timisoara. Available at http://www.capival.eu/images/guide.pdf [Retrieved on December, 2014]

Zepeda, S. J. (2011). Professional development: What works (2nd ed.). Larchmont, NY: Eye on Education.

Ксендзова, Г. Ю. (2001). Оиеночная деятельность учителя. М.: Педагогическое общество России.

www.capival.eu

www.valnetlatvia.eu 